\title{
LENNART VON POST AND THE FOUNDATION OF MODERN PALYNOLOGY
}

\author{
A. A. MANTEN \\ Secretary and Editor, Second International Conference on Palynology, Cortezlaan 9, Utrecht \\ (The Netherlands)
}

(Received July 16, 1966)

\section{SUMMARY}

A short historical survey is given of the various kinds of pollen studies that had already been started before the twentieth century: pollen morphology, the identification and treatment of pollen-induced diseases such as hay fever, and the analysis of the origin of honey by its pollen content. Observations on fossil pollen are mentioned, which prepared the way for the studies by Von Post. Also described is the development in the peat studies of Von Post, which led to the method of pollen analysis and the introduction of the pollen diagram, in 1916. This opened a gateway to a most fruitful field of modern scientific activity, now half a century old, which is only very briefly discussed here.

\section{INTRODUCTION}

It is generally difficult to establish when the development of a particular branch of science began. This also applies to palynology. Although the year 1916, when Lennart von Post presented the first modern percentage pollen diagram, is widely held to mark the foundation of what we now call palynology, palynological history actually goes back much further in time.

\section{POLLEN MORPHOLOGY}

In fact, the study of pollen grains began in the middle of the seventeenth century. This was due to an improvement in the construction of microscopes. Although there is some evidence that even the ancient Greeks had simple lenses and understood the principles of magnifications, it was not until Hooke constructed his compound microscope that an instrument was available of sufficient power to reveal anything of the shapes of pollen grains. Ever since then, the advance of 
pollen morphology has been closely associated with notable improvements in the development of the microscope.

Three centuries ago, both Marcello Malpighi and Nehemiah Grew observed and described pollen. Although the formor lived in Italy and the latter in England, they knew about each other's work and borrowed freely from each other, always with full acknowledgement. The question of priority does not seem to have interested them, and together they are recognized as the co-founders of microscopic plant anatomy and through that, also of pollen-grain morphology. The greatest contribution to the latter field came from Grew, who clearly established that, although pollen grains tend to be globular in form. they are of different size and form in different species, but those of the same species are all alike.

Since Malpighi and Grew, there have been many botanists who have contributed to our knowledge of pollen morphology. They wannot all be mentioned here. An exception, however, should be made for three German seientists. The first one is $\mathrm{H}$. von Mohl, who published, in 1834, the first detailed descriptive classification of pollen forms. The second is C. J. Fritzsche, who lived around the middle of the nineteenth century and did most of his work in Russia. He observed and pictured the fine structure of the pollen wall very accurately. The third is C. A. H. Fischer, who lived about half a century later. Only his late nineteenth-century work dealt with pollen. He studied thoroughly the pollen of about 2,200 plant species, a much more complete study than any which had been made before.

\section{POLLEN AND ALLERGIES}

The role played by some pollen spacialists in the study of eertain allergies is another line of development within palynology which originated long before Lennart von Post. Many people are sensitive or susceptible to pollen of certain plants and thus suffer from an allergy which is popularly called hay fever. This name was given because it commonly occurred during the hay season and was in use even before its cause was understood.

\section{Cause of hay fever.}

The study of hay fever is generally accepted to have started with a paper which John Bostock read, in 1819, before the Medico-Chirurgical Society of London (BosTock, 1819), and in which he presented a description of his own case. There seems to have been one earlier observation of the affection, by Heberden (to which BosTock referred, 1828), but without understanding the essentials of the disease. In the intervening 9 years, between the first and second papers, Bostock saw or received "distinct accounts of eighteen cases", besides about ten others in which "the accounts were less perfect". Study of this material enabled 
him to give, in 1828, a rather lengthy and exact account of the symptoms of the disorder, which he called "catarrhus aestivus" of "summer catarrh".

In the next 25 years or so, very little literature was produced on hay fever, but thereafter, either because of increased attention or because of greater prevalence of its causes, a distinct increase in the number of articles about the disease appeared in medical periodicals and also a number of monographs was published on the subject. They show a great variety of opinion about the causes and nature of hay fever. In this period, Charles Harrison BlACKLEY (1873) demonstrated that the catarrh is due to exposure to the pollen from certain plants. However, his observation received scant attention, because it did not explain why only certain persons should experience illness from contact with pollen but not the majority of people, and because the theory offered nothing new in treatment (VAUGHAN and BLACK, 1948), even though it was recognized that a sea voyage or sojourn at the seashore often gave relief.

An isolated subsequent attempt to apply the pollen-counting methods of Blackley was made, in 1888, by Samuel Lockwood of Freehold, New Jersey. Because of his own hay fever, he was accustomed to spend his summers at Bethlehem, New Hampshire. During the season of 1889, he exposed two series of daily pollen slides, one in Freehold and one in Bethlehem. The report states that large quantities of ragweed pollen were found on the slides at Freehold and none at all at Bethlehem. The study was not continued because the hotel keepers in the White Mountains refused to furnish funds for such research (DURHAM, 1948). No further aerobiological research was attempted until 1916, when William Scheppegrell began his local sampling and counting in New Orleans (SCHEPPEGRELL, 1923).

\section{Nature and treatment of hay fever}

At the end of the nineteenth century, it was shown that a poison of animal origin might be toxic and that an antivenin might be made which would counteract its toxic activity, also that therapeutic antibodies could be produced against bacterial toxin. As a logical extension of this kind of research, the German Dunbar (American by birth) tried, in 1905, to produce an antitoxin which would counteract the poisonous element in pollen. He injected pollen from the cereal grains into horses and marketed the serum from animals so treated under the trade name "Pollantin"; it had to be sprayed upon the nasal mucous membranes of hay fever sufferers. Another German, Weichardt, produced a serum, "Graminal", from cattle which had simply been fed large quantities of grain containing pollen. Both serums were unsuccessful for the simple fact that, as later research proved, no toxin is formed or secreted by pollen.

At about this time, Von PRIQUET (1906) introduced the term allergy to indicate a state of altered response, altered energy or altered reactivity. His collaborator, Doerr, elaborated this definition to include all forms of altered reactive capacity, 
irrespective of the presence or absence of antigen-antibody reaction. In this sense, the definition is still appropriate today (VAUGHAN and BLACK, 1948).

A new element in hay fever research was brought forward by Weichardt, in 1905, and Wolff-Eisner, in 1906, who suggested that hay fever may be an anaphylactic phenomenon. The concept of anaphylaxia, which had just been clearly developed at that time by the Frenchman Richet and his associates, the German Otto, and the Americans Rosenau and Anderson, implied the destruction of a normal or natural immunity factor during an incubation period. It was, finally, the Englishman Leonard Noon who, in 1911, could definitely prove this. He was also the first to successfully treat pollinosis with pollen extracts. He applied preseasonal (prophylactic) treatment to his patients, naturally so, because this method duplicated insofar as practicable the experimental production of the state of antianaphylaxis.

Two other methods of desensibilization which are at present generally used, were introduced later. These are coseasonal (phylactic) and perennial therapy. WALKER (1921) was the first to write that in cases where preseasonal treatment led to little or no improvement, pollen-extract injections may be continued, but in smaller amounts. Soon after, VAUGHAN (1923) also found that in several cases this leads to good results and since then, the coseasonal therapy has become recognized in routine pollen therapy. WALKER (1920) was also the first to suggest that if pollen cases were treated long and consistently, many patients would possibly be entirely free from symptoms for years, if not throughout life. The first two comprehensive reports on perennial treatment were those by A. BRowN (1927) and by VANDER VEER et al. (1927), who all observed good results. When in the next few years, others also reported success, such treatment became an accepted procedure.

Further details about the history of the study of hay fever can be found in the books by CocA et al. (1931) and Durham (1936).

\section{STUDIES OF POLLEN IN HONEY}

In 1895, PFISTER showed that it is possible to establish the geographical and botanical origin of honey by identifying the pollen grains which are contained in the honey. About ten years later, this discovery was followed by research by YounG (1908) and Fehlmann (1911), who worked on American and Swiss honey, respectively. Fehlmann's work is particularly noteworthy in that it contains, for the first time, a distinction between the honey of flowers and the honey dew, on a microscopic basis.

In the early nineteen-thirties, the microscopic examination of honey was taken up again in Germany. The subject was developed mainly by Armbruster and co-workers, Griebel, and especially by Zander, who through his enormous amount 
of work, laid down the foundations of the microscopic determination of the origin of honey. During the following years, the microscopic analysis of honey was developed also in various other countries of Europe. With the increased activity in modern pollen morphology, which has taken place since the second half of the nineteen thirties, closer contacts were sought with pollen students also outside the own group of honey researchers. The study of pollen in honey is now known under the name of melittopalynology.

\section{VON POST'S PREDECESSORS}

In order to specifically identify seeds and other small fossils found during the examination of peat, lignites and coals, some strong magnification was required. Its use should quite naturally result in the discovery of even smaller fossils, including pollen grains.

Fossil pollen was nevertheless observed for the first time, not before February 1836. This was by H. R. Göppert, in material collected from the Miocene browncoal of Salzhausen in Hessen, Germany (GöPPERT, 1936). In 1837, C. G. EHRENBERG found Pinus pollen in a Quaternary sediment from northern Sweden. In 1838, he found Pinus-like pollen in a Cretaceous flintstone and, in 1839, also in several Tertiary browncoals in western Germany. In 1841, GöPPERT also described fossil pollen grains of the Pinaceae from the palaeobotanically well-known site at Radoboj, near Varazdin, where many leaf remains occur in a Tertiary limestone. The pollen grains were collected through a treatment of the rock with diluted hydrochloric acid and appeared to be well-preserved. As a result of this, he became the first to make a general plea for taking up (certainly only qualitatively) the inventory of the pollen content of sedimentary deposits. Scattered notes on other observations of plant microfossils, ranging from Cretaceous to Quaternary in age, can be found from then on in nineteenth-century scientific literature (e.g., VoN DUISBURG, 1860; Fresenius, 1860). In addition to Göppert and Ehrenberg, the Swiss F. E. Geinitz and J. Früh should also be counted among the pioneers of palaeopalynology. They recognized the importance of pollen in peat in relation to the problem of origin and composition (see GeinITz, 1887).

A quantitative presentation of pollen-analytical data, and even in relative figures, is found for the first time with WeBER $(1893,1896)$. As a plant physiologist (he was the last assistent of the famous Julius Sachs, of Würzburg), however, he was so afraid of making errors in interpreting his pollen-analytical results that he did not develop this new line further. In the Nordic countries, the Dane Sarauw (1897) was the first to present quantitative information, but without giving percentages. The eminent leader of the palaeofloristic school in northern Europe, the Swede G. Andersson, paid much attention to diatoms, but apparently never attached much importance to the occurrence of pollen grains and spores in the 
deposits which he studied (see ANDERSSON, 1898).

When, by the end of the eighteen-nineties, Gustaf Lagerheim began to assist Swedish and Danish peat investigators by identifying pollen grains for them, the basic principles of pollen analysis had already been laid down. In Finland, Harald Lindberg found that the percentages of certain pollen grains can differ in successive layers. In 1905, Lagerheim who had, thus far, only been working qualitatively, made a similar observation in Sweden (see the table which he contributed to WITTE, 1905).

It was through Lagerheim, who made pollen and spore identifications from material collected by Von Post in his first own investigations, that Von Post learned to see the value of plant microfossils.

At that time, there was also already some insight into the chronology of the Postglacial. In 1876, the Norwegian Blytt had developed a theory about climate in his country in Postglacial time. Based upon the penetration in Norway of the present flora, he distinguished a few warmer and cooler, dryer and wetter periods.

This theory was further extended by the Swede SerNander $(1908,1910)$, who made it more generally applicable. The successive periods have since been known as the periods of Blytt-Sernander.

\section{LENNART VON POST}

Ernst Jakob Lennart von Post was born on June 16, 1884 in Johannesberg, Lundby Parish, not far from Västerås, in the Swedish province of Västmanland. His father was a judge-advocate in the Swedish army, although he also served at different times as a civilian lawyer or as assistant cantonal judge and was sometimes a farmer as well. Several of his paternal forebears were military officers. His great-grandfather, Major Olof Jakob Rangel was adopted, in 1809, under the name Von Post. The family line goes back for several centuries, and was initially concentrated in the village Rangedal, in Rångedala, in the province of Västgötland.

Lennart von Post's mother, Beata Jacquelina Charlotta Christiana Nisbeth (generally called Jacqueline), died a year after his birth, and he had no brothers or sisters. He was brought up mainly by his father. He completed his secondary school education in June 1901, when not yet 17 years old and the following autumn he became a student at the famous university of Uppsala.

Initially it was Lennart's intention to study zoology, but soon, however, he became fascinated by the lectures of A. G. Högbom, and these converted him to geology. He also established close contacts with the stimulating Rutger Sernander, the man who had extended Blytt's subdivision of the Postglacial to the wellknown Blytt-Sernander chronology.

On March 5, 1902, Sernander gave a lecture on the marshes of the Baltic island of Gotland. The immediate cause of the lecture was the planned reclamation 
of one of the main marshes, the Mästermyr, and the immediate result was Von Post's first scientific task, that of preparing a report about the history of development of the Mästermyr. In cooperation with Jakob Ljungqvist, who studied plant sociology, he worked in Gotland, where he lived with and like the local farmers.

It took a quarter of a century before the results of his study of the Mästermyr were printed. This was in the description attached to the geological map sheet Hemse, which appeared in 1927. The first scientific contribution by Von Post, which appeared in print, was a description of the Littorina wall at Snoder, Sproge Parish, Gotland, which he completed in the autumn of 1903.

In three years Von Post completed the studies for his bachelor degree and in December 1907, he obtained his "licentiat" (a degree roughly comparable to a master degree). His master thesis dealt with peat swamps in Norrland. When drawing up a scheme of the history of the swamps, he met with serious difficulties in establishing ages. In south and central Sweden archaeological finds and elevated beach lines did give some help, but in the north he could only make extrapolations. He himself doubted if his datings were correct except in incidental cases only. Nevertheless, his peat-swamp studies were considered good enough to be rewarded with the Linnaeus Prize, which he received in 1906, when only 21 years old.

In 1908, Von Post left his post of "amanuens" (assistant) at the geological institute of the university for a similar position with the Swedish Geological Survey. He remained with the Survey for 21 years and it was in this period that he carried out his best-known studies. He was the specialist in peat areas. In addition to geological studies, he also carried out plant-sociological studies of the Skagershult peat swamp, in 1907. The results were published in a guide book to the Eleventh International Geological Congress (VON PosT, 1910) and comprise, among other things, the first maps of Swedish swamp vegetation, which were also internationally among the first detailed studies of this kind.

During further work on the swamps of the province of Närke (west of Stockholm), in 1908, he was puzzled by the question of whether some stub horizons were synchronous-as Sernander assumed —or not. To find a solution, he began to use pollen grains stratigraphically and this led to the introduction of the "spruce boundary" or "spruce-pollen boundary" which he found useful in local correlations (VON Post, 1909).

In 1909, a work by HoLst on Postglacial age determinations also appeared. In it, Lagerheim gave a detailed analysis of the pollen which he had observed in samples from the Kallsjö swamp in Skurup (Scania). For two layers, he had made percentage calculations for pine (Pinus), birch (Betula), alder (Alnus), elm (Ulmus) (all decreasing upwards), ash (Fraxinus), oak (Quercus), lime (Tilia) (increasing) and hazel (Corylus) (not included in the pollen sum, as in later pollen analyses). Holst was rather impressed by these results and wrote that this was a certain method for following carefully, with the aid if a microscope, layer after layer, 
of both the immigration of all plants of which pollen or spores occur fossilized, and also alterations with respect to the relative numbers of these plants. ${ }^{1}$

Initially, Von Post still went on using his spruce-pollen boundary but gradually, however, he came to the conclusion that this was insufficient by itself. When he wished to show that the "Grenzhorizont" of Weber really existed (VoN Post, 1913), he went one step further and prepared a table of the Picea/Pinus ratio in successive layers. When he wished to follow the same method to demonstrate the boundary in Scania, he met with more difficulties. First he tried to solve these by looking for a beech-pollen boundary but this was also not satisfactory, so he started counting all arboreal pollen. He was fortunate in obtaining good material, at that time, in 1915, from the Bjärsjölagård swamp in southern Scania. When he saw the results, he became so enthusiastic that he also started revising his material from Närke.

The work, started by Weber and Lagerheim, was now brought to fruition by Von Post. Pollen analysis, a new excellent method for stratigraphic study had been discovered, with the pollen diagram as its black-and-white product.

The first time that Von Post presented this method to a large public was in a lecture at the Sixteenth Scandinavian Meeting of Natural Scientists, in Christiania (now Oslo), in 1916. The lecture was entitled "Skogsträdspollen i sydsvenska torvmosselagerföljder" (Arboreal pollen in successions of peat-swamp layers of southern Sweden). The text of the lecture was only published two years later (VON PosT, 1918). Consequently, it does not contain the first pollen diagrams that appeared in print. These appeared in a contribution to the Bulletin of the Geological Institutes of Upsala (VoN PosT, 1916).

In describing the remaining part of Von Post's life only shortly, the intention is not to depreciate in any way the merits of his later work. He continued his peat studies but he also worked on such subjects as elevated beach lines and engineering geology (he was a member of the Geotechnical Commission of the State Railways, 1914-1922). In 1929, he was appointed professor of geology at Stockholms Högskola (the University College, now University of Stockholm), to occupy the chair formerly held by Gerard De Geer, who earned world fame through his studies of varved clays. In 1939, Von Post was nominated as a member of the Royal (Swedish) Academy of Science. Several nominations to other societies, both domestic and foreign, followed, as well as prizes. Honorary doctorates were awarded to him by Stockholms Högskola (1927) and by the universities of Königsberg (now Kaliningrad) (1941) and Copenhagen (1950). He died on January 11, 1951 .

\footnotetext{
1 “. . . en säker metod att på mikroskopisk väg . . . lager efter lager noggrant följa såväl invandringen af alla de växter, hvilkas pollen eller sporer uppträda fossilt, som också förandringarna i afseende på dessa växters relativa antal".
} 
Whereas in the years before Von Post's first pollen diagram, pollen morphology, hay fever research, studies of pollen in honey, and also observations on fossil pollen were the work of only a very limited number of scientists, Von Post had, in his work, now opened up a line of development which was full of potential. Soon the number of scientists interested in pollen studies began to increase rapidly. Quaternary geologists and palaeobotanists, and archaeologists produced a growing number of successful studies. Knowledge of Quaternary plant geography was extended in a revolutionary way and the pollen diagrams which showed very clearly the successive periods of the Blytt-Sernander chronology, became an indispensable stratigraphical tool. The study of fossil pollen was given fresh incentives when it was shown, first in the U.S.A., that the method of pollen and spore analysis could also be used profitably for the identification and correlation of coal seams and coal-bearing rocks. The technique of pre-Quaternary pollen analysis was particularly strongly expanded and refined in Germany.

While studies of pollen were thus expanded, a growing dissatisfaction developed among the scientists involved concerning the name of their field of scientific activity. The term "pollen analysis", most commonly used, "refers only to the method of getting certain data which in itself has little purpose and ... does not apply to or cover all the branches of the pollen studies, much less the application of the direct results to climatic conclusions, etc. It is the knowledge gained from the pollen studies, be those statistical or morphological, or be they concerned with pollen-induced diseases as hay fever, etc., that has purpose and significance (ANTEVs, 1944). Another reason why the name pollen analysis was not longer satisfactory, was that in the analysis use was made also of spores of ferns and mosses, and of other micro-organisms. In the discussion, which followed the above remarks, HYDE and WILLIAMS (1944) suggested "palynology" as a better alternative. The word is derived from the Greek $\pi \alpha \lambda v v \omega$ (palyno), which means to strew or sprinkle, and is suggestive of $\pi a \lambda \eta$ (palé), fine flour, which is cognate with the Latin pollen, flour, dust. The new name was very readily accepted.

The sharply increased amount of work on fossil pollen also called for an increase in the amount of studies concerning modern pollen. Von Post clearly realized this also. In a communication to the Swedish Minister of Education, dated May 10,1947, he pointed out that it would be "most desirable that the morphology and systematics of pollen and spores be subjected to an all-round and thorough investigation"1. Such independent palynological research would "no doubt throw an extremely valuable, often piloting light upon plant interrelationships

\footnotetext{
1 “... vore $i$ hög grad önskvärt att pollenets och sporernas morfologi och systematik underkastades ett allsidigt, i grunden gående studium".
} 
and upon the evolution of the plant kingdom"1. These lines show that Von Post had an open eye for what palynology could mean also outside the field of pollen statistics and its bearing on palaeoclimatology and geochronology.

There is no doubt that the successful utilization of plant microfossils in stratigraphic work of petroleum geology, during the last two decades, has given modern palynology its greatest impetus. In the nineteen-fifties, the total activity within palynology expanded with a factor of probably about 10 . Also the study of other groups of microfossils, such as acritarchs, dinoflagellates and chitinozoans, is now considered by several scientists to form part of modern palynology. A controversial matter, in which palynology has recently become involved is the question of whether carbonaceous chondrites contain traces of extraterrestrial life.

A more detailed historical review of the history of palynology since Von Post is published elsewhere (MANTEN, 1966).

\section{A TASK FOR THE IMMEDIATE FUTURE}

When thinking about the future of palynology, it is easy to lose oneself in day-dreaming. I will try to prevent this by emphasizing just one aspect that needs to receive full attention in the years ahead, if palynology is to maintain the important place which it has come to occupy in the past decades. This concerns the need for more team work between researchers of different backgrounds.

From the foregoing it is clear that palynology naturally has all the potentialities of an interdisciplinary field. A true interdisciplinary field is characterized by a relatively high degree of team work, which among other things, is reflected by a high percentage of scientific publications appearing under multiple authorship (MANTEN, 1967). If this percentage is calculated for palynology, one finds, however, that it is closer to the figure obtained for geology, than to the percentages of multiple authorship in geophysics and geochemistry. In reality, thus, palynology is not the interdisciplinary field that it could be. Most of the workers restrict their activities to their own field of specialization.

The situation is even more critical if we look at the development in the percentage of multiple authorship over the last 10 years. In most branches of science, we then find a rather gradual increase. But not in palynology, where the percentage for all that time has remained around 30. Palynology is getting left behind in the tendency which is prevalent in scientific work in our time!

In actual fact, this shows that the use of palynomorphs in stratigraphical and palaeoecological studies has reached far ahead of the basic research in palynology. Historically, this is understandable, but nevertheless, it is increasingly

1 "... utan tvivel att kasta ett synnerligen betydelsefullt, i många fall vägledande ljus över växtformernas inbördes släktskapsförhållanden och över växtrikets utvecklingshistoria". 
dangerous. Much more fundamental research is needed to develop and validate the principles which may be used to establish and/or to develop further both the areas of applicability and the limitations of palynology. This requires, even more strongly than at present, the joining of experience, knowledge and energy of workers with different backgrounds and specializations. Before anything else, this development needs to be stimulated and supported and may I urge every palynologist to see his own task as one which will help achieve this aim in the years directly ahead.

\section{ACKNOWLEDGEMENTS}

The author is indebted to Professor O. H. Selling for his permission to make free use of information contained in his necrology of Lennart von Post (Selling, 1951), to Professor G. Erdtman, for drawing his attention to the letter of Von Post to the Swedish Minister of Education, 1947, and to Professor F. P. Jonker, for critical reading of parts of his manuscript.

\section{REFERENCES}

ANDERsson, G., 1898. Studier öfver Finlands torfmossar och fossila Kvartärflora. Bull. Comm. Géol. Finlande, 8(1898).

Antevs, E., 1944. The right word? Pollen Analysis Circ., 6: 2-3.

BLACKLEY, C. H., 1873. Experimental Researches on the Causes and Nature of Catarrhus Aestivus (Hay-fever or Hay-asthma). Baillière, Tindall and Cox, London, 202 pp. Reprinted in 1959 by Dawson's of Pall Mall, London.

Bostock, J., 1819. Case of a periodical affection of the eyes and chest. Medico-Chir. Trans., 10(1): 161-165.

BosTock, J., 1828. On catarrhus aestivus, or summer catarrh. Medico-Chir. Trans., 12: 437-446.

BRown, A., 1927. New plan for applying specific treatment of pollen hay fever (perennial treatment); preliminary report. J. Immunol., 13: 273.

Coca, A. F., WAlzer, M. and Thommen, A. A., 1931. Asthma and Hay Fever in Theory and Practice. Charles C. Thomas, Springfield, Mass.

DurHam, O.C., 1936. Your Hay Fever. Bobbs-Merrill Company, Indianapolis, Ind.

Durham, O. C., 1948. Aerobiology: development and technic. In: W. T. Vaughan and J. H. Black (Editors), 1948. Practice of Allergy. Mosby, Saint Louis, Mo., pp.451-464.

EhrenBerg, C. G., 1837. Verhandl. Preuss. Akad. Wiss. Berlin, 1837: 44.

Fehlmann, C., 1911. Beiträge zur mikroskopischen Untersuchung des Honigs. Mitt. Schweiz. Gesundh. Amtes, Bern, 2: 179, 211.

Fresenius, G., 1860. Uber Phelonites lignitum, Phelonites strobilina und Betula salzhausenensis. Palaeontographica, 8: 158.

GeinItZ, F. E., 1887. Geologische Notizen aus der Lüneburger Heide. Jahresh. Naturwiss. Ver. Fürstentum Lüneburg, 10: 36.

GöpperT, H. R., 1836. De floribus in statu fossili commentatio. Nova Acta Acad. Leopoldina Carol. Natur. Cur., 18(1): 547-572. Also issued as an independent publication, Breslau, 1837. Cf. also Neues Jahrb. Mineral. Geol. Paläontol., 1836: 361; 1837: 725.

GöPPERT, H. R., 1841. Uber das Vorkommen von Pollen im fossilen Zustande. Neues Jahrb. Mineral. Geol. Paläontol., 1841: 338-340. 
GöppERT, H. R., 1855. Die tertiäre Flora von Schossnitz in Schlesien. Görlitz.

Holst, N. O., 1909. Postglaciala tidsbestämningar. Sveriges Geol. Undersökn., Arsbok, Ser. C: Avhandl. och Uppsat., 216.

Hyde, H. A. and Williams, D. A., 1944. The right word. Pollen Analysis Circ., 8: 6.

Manten, A. A., 1966. Half a century of modern palynology. Earth-Sci. Rev., 2(4): in press.

MAnten, A. A., 1967. Multiple authorship in the earth sciences. Earth-Sci. Rev. (Atlas), in preparation.

Pfister, R., 1895. Versuch einer Mikroskopie des Honigs. Forschungsber. Lebensm. Bez. Hyg. Chem. Pharm. (München), 2: 1-9, 29-35.

Sarauw, G. F. L., 1897. Cromer-skovlaget i Frihavnen og traelevningerne i de ravførende sandlag ved København. Medd. Dansk Geol. Foren., 4: 17-44.

SCHEPPEgRELl, W., 1923. Analysis of six annual seasons of fall hay fever in New Orleans, Louisiana. Publ. Health Dept. (U.S.), 38: 1565.

Selling, O. H., 1951. Lennart von Post, 16/6 1884-11/1 1951. Svensk Botan. Tidskr., 45(1): 275296.

SERnANDER, R., 1908. On the evidences of Postglacial changes of climate furnished by the peat mosses of northern Europe. Geol. Fören. Stockholm Förh., 30: 465-473.

Sernander, R., 1910. Die schwedischen Torfmoore als Zeugen postglazialer Klimaschwankungen. In: Die Veränderugen des Klimas seit dem Maximum der letzten Eiszeit. Exekutivkomitee des 11. internationalen Geologenkongresses, Stockholm, pp. 197-246.

Vander Veer Jr., A., CoOke, R. A. and Spain, W. C., 1927. The diagnosis and treatment of seasonal hay fever. Am. J. Med. Sci., 174: 101.

Vaughan, W. T., 1923. Specific treatment of hay fever during the attack. J. Am. Med. Assoc., 80: 245 .

Vaughan, W. T. and Black, J. H., 1948. Practice of Allergy. Mosby, Saint Louis, Mo., 1132 pp.

Von DuIsburg, H., 1860. Urweltlicher Blütenstaub. Neues Preuss. Provinzialbl, III Folge, 5: 296. Cf. Amtliche Ber., 35; Verschlag Deut. Naturforsch.usw. Königsberg, 1860(1861): 291, und Schrift. Physik.-ök. Ges. Königsberg, 3: 31-32(1862).

Von Pirquet, C., 1906. Allergie. München. Med. Wochenschr., 53: 1457.

VoN Post, L., 1903a. En profil genom högsta Litorinavallen på södra Gotland. Geol. Fören. Stockholm Förh., 25(5): 257-258 (report of lecture).

VON Post, L., 1903b. En profil genom högsta Litorinavallen på södra Gotland. Geol. Fören. Stockholm Förh., 25(6): 339-372.

VON Post, L., 1909. Stratigraphische Studien über einige Torfmoore in Närke. Geol. Fören. Stockholm Förh., 31(7): 629-706.

Von Post, L., 1910. Das Skagershultmoor. In: L. voN Post und R. SERnander. Pfanzenphysiognomische Studien auf Torfmooren in Närke. Intern. Geol. Congr., IIth, Stockholm, Congr. Guide 14 (Excursion A7): 1-24.

Von Post, L., 1916. Einige südschwedischen Quellmoore. Bull. Geol. Inst. Univ. Upsala, 15: 219-278.

VON Post, L., 1918. Skogsträdspollen i sydsvenska torvmosselagerföljder. Forh. Skand. Naturforskeres 16. mote, 1916, pp.432-465.

Von Post, L., 1927. Myrmarker. In: H. Munthe, J. E. Hede and L. Von Post. Beskrivning till Kartbladet Hemse. Sveriges Geol. Undersökn., Ser. Aa, 164: 101-138.

WAlker, I. C., 1920. Frequent causes and the treatment of perennial hay fever. J. Am. Med. Assoc., 75: 782 .

WALKER, I. C., 1921. Frequent causes and the treatment of seasonal hay fever. Arch. Internal Med., 26: 71 .

Weber, C. A., 1893. Über die diluviale Flora von Fahrenbrug in Holstein. Botan. Jahrb., 18, Beibl. 43.

WITtE, H., 1905. Stratiotes aloides L. funnen i Sveriges postglaciala avlagringar. Geol. Fören. Stockholm Förh., 27(7): 432.

Young, W. J., 1908. A microscopical study of honey pollen. U.S. Dept. Agricult. Bull., 110: 70-93. 